\title{
中学校における生徒の場所の想起と居場所の選択に関する考察 A STUDY ON THE STUDENT'S REMEMBARANCE OF IMAGE SCENERY AND SELECTION OF PLACE IN JUNIOR HIGH SCHOOL
}

\author{
常陰有美*, 倉斗綾子**, 新田佳代***, 上野＼cjkstart淳**** \\ Yumi TSUNEKAGE, Ryouko KURAKAZU, Kayo NITTA \\ and Jun UENO
}

\begin{abstract}
The purpose of this study is consideration about junior high school as living space through investigation into student's remembarance of image scenery and selection of space.

Main result shows as follows.

1)Space composition have a great influence on student's remembarance of image scenery and selection of space.

2) Student's favorite space is difference from space where they really stay.

3)Various space acd equipment make student's living activity diverse.
\end{abstract}

\section{Keywords : Junior High School, remembarance of image scenery, selection of space, Rest Time} 中学校, 場所の想起, 居場所選㘮，休み時間

\section{1. 背景と目的}

中学生は心身ともに大きく成長を遂げる多感な時期にあり，その 多くの時間を中学校において過ごす，彼らが中学校という空間をど のようにイメージ，認識し，赛際にどのように居場所を選択してい るかは，興味深い課題であり，中学校を計画する上でも重要なテー マとなりうると考えられる.

教科教宔型運営やメディアスペースを基調とした中学校計画に対 する関心が高まる中で，中学校空間に㧍ける居場所選択に着目した 既往諭女も散見できる，この中には，中村・西村らによる居場所と 行動特性に着目したもの主1)や，瀧山・西村らによるホームベース における居場所形成に着目したもの注2〉などが挙げられる。しかし， それらは学校空間を部分的に捉えたものや行動現象としての生徒の 居場所選択を捉えたものが多く，生徒の視点から見た中学校空間に 対する認識等の全体像を据えた研究は少ない，本稿では，生徒が学 校空間全体についてどのように認識し，実際にどのように休み時間 の居場所を定めているのかを調査・分析し，生活環境としての中学 校空間の在り方を考察することを目的としている。

\section{2. 調查概要}

本研究では中学校の建宓形態を仕米的な片激下型平面を基調と
する従来型，サープンなメディアスペースを教室ま加りに配するメ ディアスペース型（以下；MS型）の2つに分類する.また連営力 式を，特別教室型 (以下: 特教型)，教科教室型（以下：教科型）， 従来型校舎の余裕教室を工夫して活用することで部分的に教科教室 型運営を実現させている一部教科教空型（以下：一部型）の3つに それぞれ分類する.これらの観点に学校規模の条件を加味して, 調 查対象校として，特教型・従来型より小規模校の $\mathrm{Mr}$ と $\mathrm{Mg}$, 大規 模校の $\mathrm{Ta}$ ，教科型・MS型より小規模校のO $\mathrm{m}$ ，大規模校のS e ， そして一部型・従来型で小規模校のN k の計 6 校を選定した（表 • 1，2）、これら対象校に全校生徒を対象とした場所の想起や休み時 間の居場所選択に関するアンケート調查と，生徒の休み時間の過ご し方の実際を把握する観察調查の 2 つのの調查（表・3）を実施し， 各校の比較及び分析を行った。アンケート調查では，害施した 6 校 より全学年 1133 名の回答が得られ，うち有效回答数は 1130 (99.7\%) であった.

\section{3. 中学校空間に対する生唗の場所の想起}

\section{1. 場所の想起}

アンケート調査では，生徒に「お気に入りの場所」，「嫌いな場所」， けひとりで過ごす場所」，「仲の良い友達と過ご才場所!の4項目につ
* 侏岡村製作所 修士(工学)

* 首都大学東京大学院建築学尃攻 COE リサーチフェロー・塍士(工学)

*** 的药地所設計建榮設計部 修士(工学)

****首都大学東京大学院建築学専政 教授・工博
Okamura Corporation, M. Eng.

Research Fellow, Graduate School of Architecture, Tokyo Metropolitan Univ., Dr. Eng.

Mitsubishi Jisho Sekkei Inc., M. Eng.

Prof., School of Architecture, Tokyo Metropolitan University, Dr, Eng. 


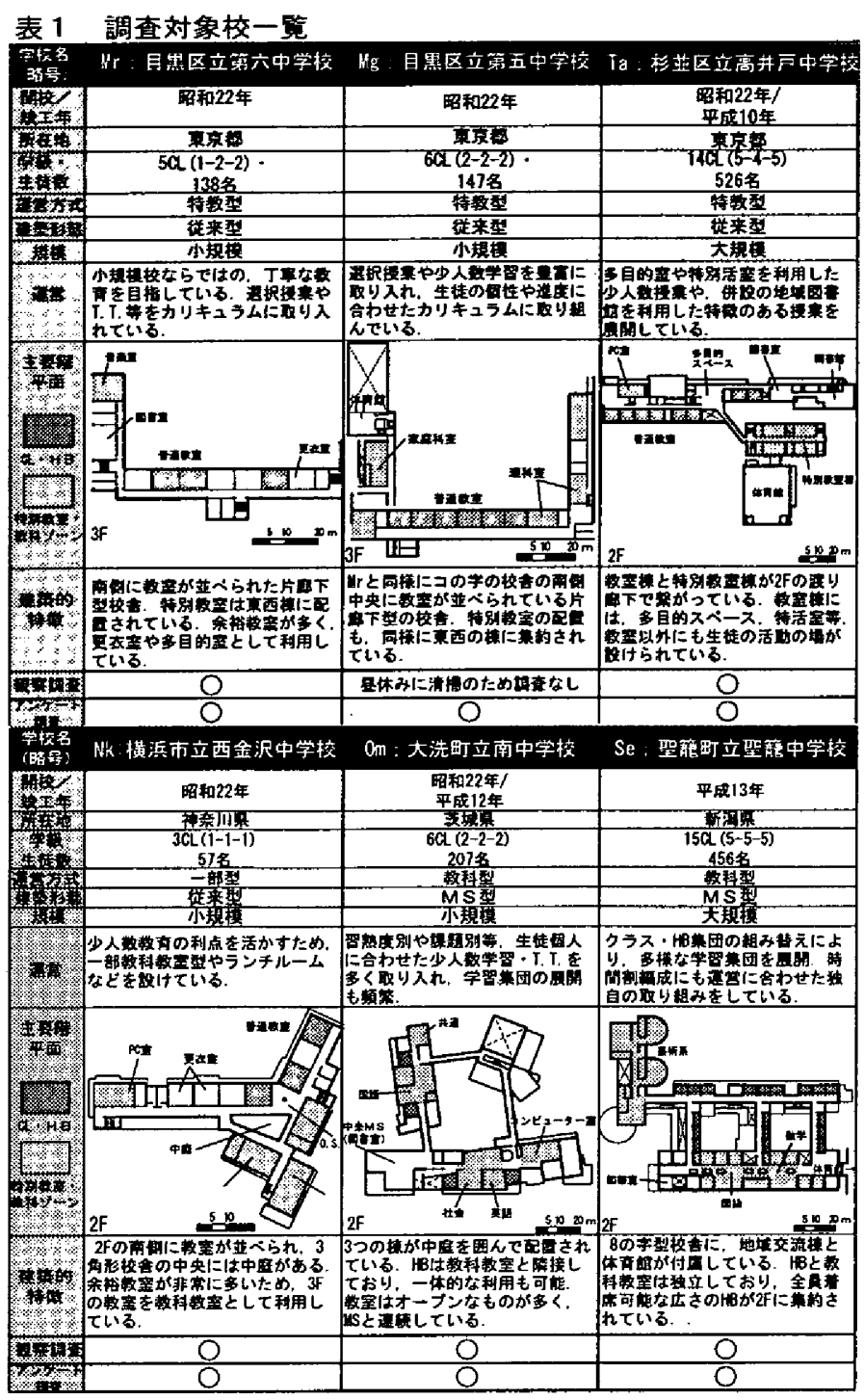

いて，校舍平面図上に図示させる調查を行っている：この場所に対 する想起の有無の割合をMS型・教科型の $\mathrm{Om}$ 校, S e 校と従来型・ 一部型の $\mathrm{N} \mathrm{k}$ ，従来型・特教型の M r の 4 校について図・1にまと めた。「嫌いな場所」，「ひとりで過ごす場所」，「仲の良い友達と過ご 寸場所」の 3 項目については，運営方式や建築形態による有意な差 異は認めることはできない。しかし、「お気に入りの場所」については， 従来型では「ある」と答えているものが50\%内外であるのに対し， 教科型・M S 型の O m校では，これよりも有意に高いことが指摘で きる．空間設定のあり方が場所の選択性に影響を与えるひとつの傾 向であると考えられる，また，「ひとりで過ごす場所」の有無につい てみると，全体の約 3 分の 1 ほどの生徒がこのような場所を意識し ていることがわかる。

\section{2. 場所想起の分布}

それぞれの項目に，校内のどのような場所が想起されているのか の寒際を，MS型であるS e 校と従来型であるM r 校について図・ 2 に分布図として示した。また校内諸スペースを表・4のように分 類した上で，各項目についてどのような場所が想起されているのか を，6校について，その割合を集計すると図・3のようになる.

1）お気に入りの場所の分布

建案形態による顕著な差は認められず，校内に広く分布している.

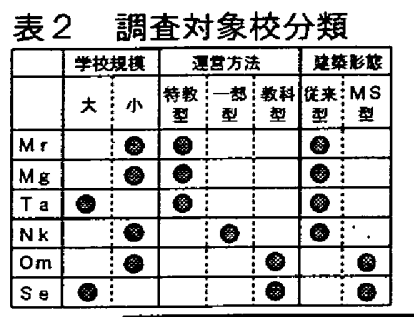

表 3 調查概要

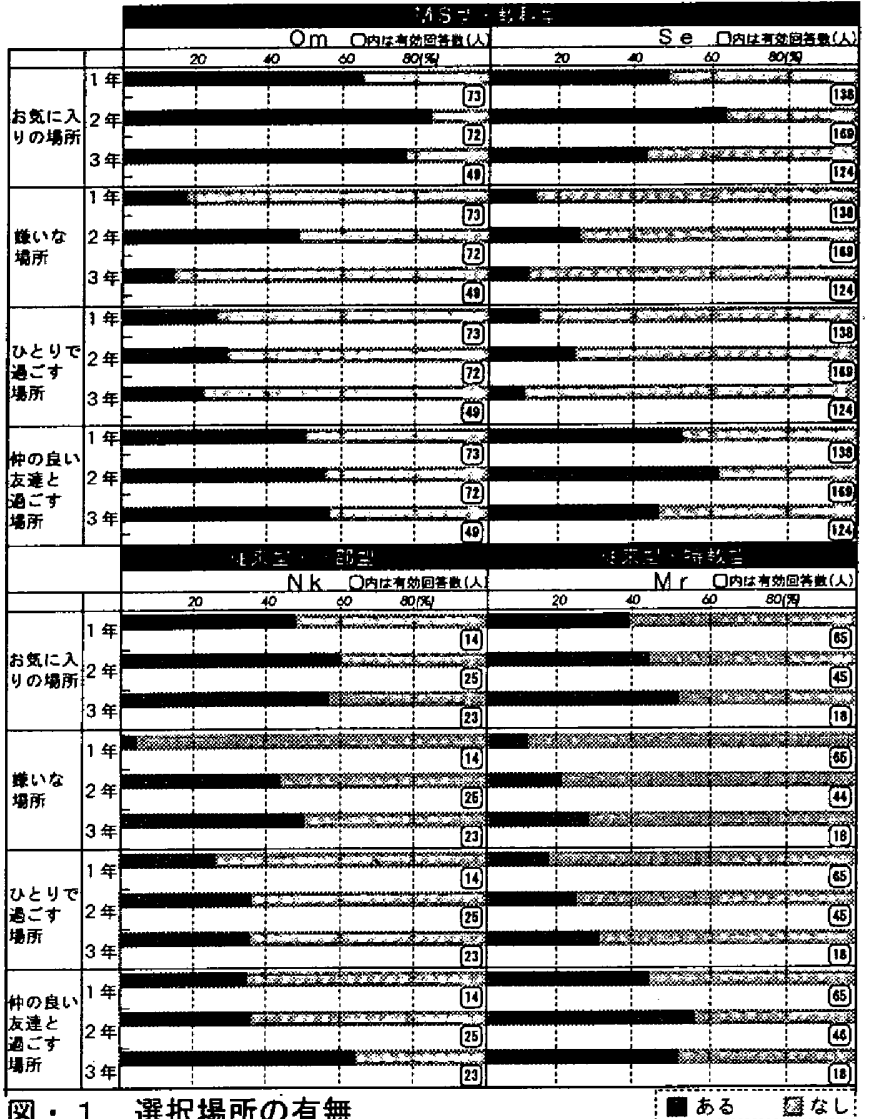

図・ 1 選択場所の有無

5.

また学年ごとの明確なすみわけは見られず，各場所に複数学年が混 在する.このような特徽から，生徒は学年ゾーンに限られることなく， それぞれ自分のお気に入りの場所を見つけているものと思われる.

2）嫌いな場所の分布

建案形態による明確な差は認められない，教室やH B は選択され にくく，特別教室や教科教室を選択する生徒が多い，その主な理由 としては，教科に対する好き嫌いなどの個人的事情や，污い，真い などといった衛生的要素に関する不満があげられる.

\section{3）ひとりで過ごす場所の分布}

MS 型のOm，S e 校では，校内にまんべんなく分布しているが， $\mathrm{Mg}, \mathrm{Mr}$ 校などの従来型校舎では, 教室・教室まわりと動線空間, トイレに分布が集中している，トイレを選択している生徒のほとん どが教室近くのものを選択しているため，これを教室まわりと捉え ると, 分布は教室・教室まわり及び動線空間に二極化していると言 える。

4）仲の良い发達との場所の分什

クラスルーム (以下：CR）やH B及びその隣接空間が想起され るため，学年ごとの領域がはっきりと区分される傾向にある，MS 型の $\mathrm{Om}, \mathrm{S}$ e 校では校内各所に分散する傾向があるが, $\mathrm{N} \mathrm{k}, \mathrm{Mg}$ ， $\mathrm{Mr}$ 校などの従来型校舎では，ほとんどの生徒がC R を選択してお 


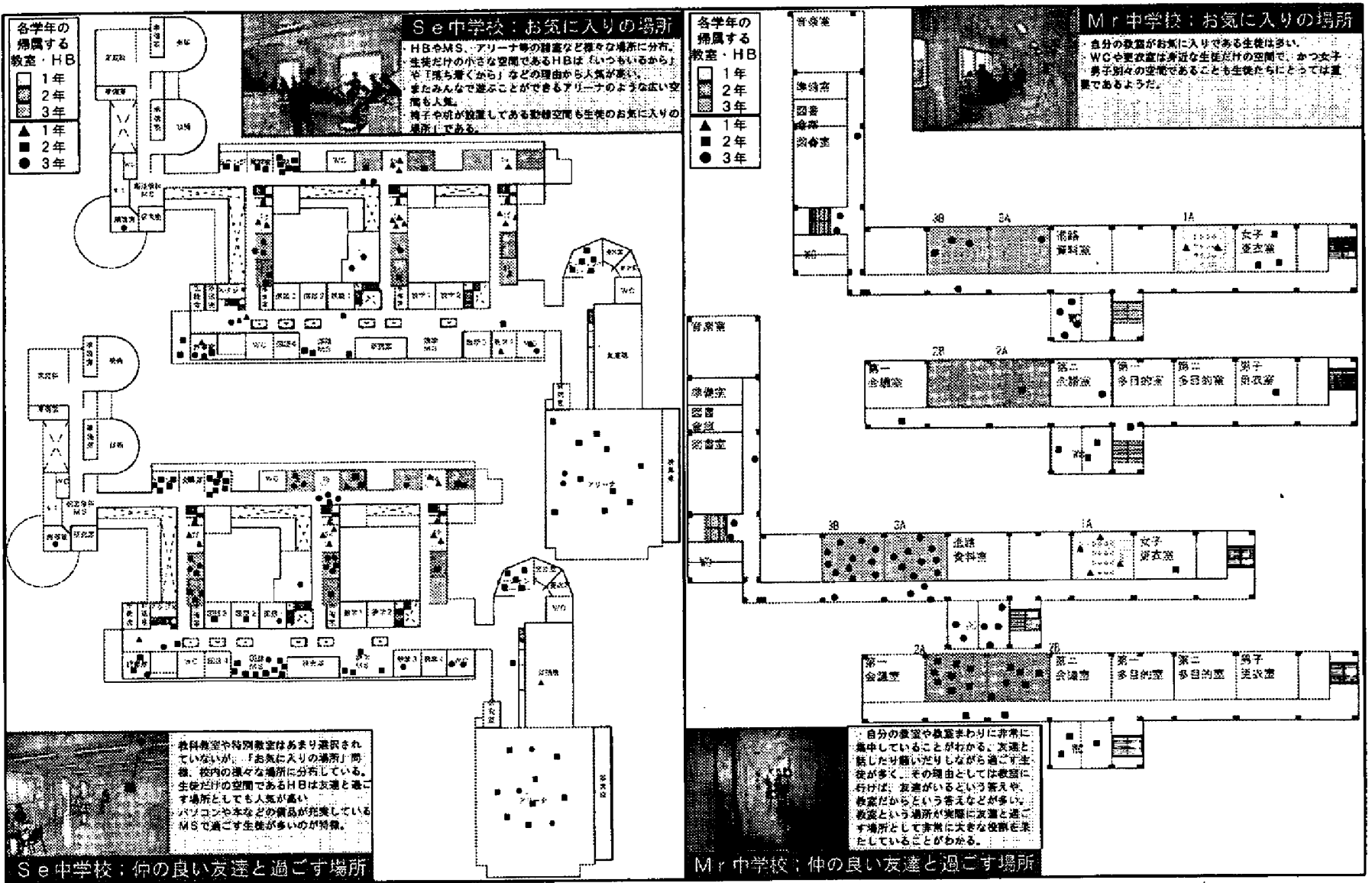

図・2 選択場所の分布（主要階における）

り，建築形態による差異が認められる。また下 a 校では，一部動線 空間に椅子が設置してあり，広いオープンスペースのように設えら れているため，教室や教室まわりからあふれ出た生徒が動線空間に 多く滞在するという傾向が見られた

\section{4、アンケート調查からみる休み時間における生徒の居場所と行為}

本章では、アンケート調查をもとに 2 時間目と 3 時間目の間の休 み時間（以下；授業間休み）と昼休みの居場所の選択と行為につい て考察老行 5 .

\section{1，休み時間における生徒の行為}

生徒の休み時閒の行為内容を表・ 5 に示すように分類した。 その うち授業淮㒉と個人の休息，その他の3つの大分類に着目し，アン
表・ 4 場所の分類

\begin{tabular}{|c|c|c|}
\hline 敬垔·HB等 & 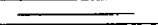 & 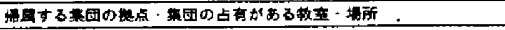 \\
\hline 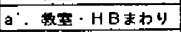 & & 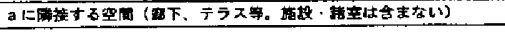 \\
\hline その䑨敖至 & & 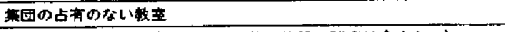 \\
\hline その地弱至末かり & $\bar{E}$ & 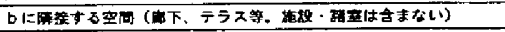 \\
\hline OSBUMS & E & 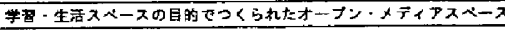 \\
\hline \multirow{5}{*}{ d. ₹の地 } & Zの他备垔 & 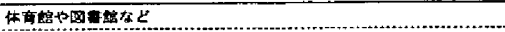 \\
\hline & 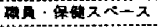 & 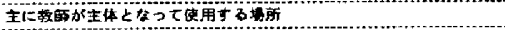 \\
\hline & 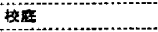 & \\
\hline & 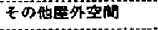 & 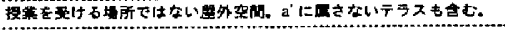 \\
\hline & Wo & \\
\hline その地期空何 & & 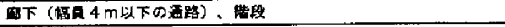 \\
\hline
\end{tabular}

ケート調查を実施した全 6 校の授業間休みの行為内容の割合を示し た (図・4)。教科型の0m校では約 $60 \%$ 生徒が授業準備をして いたと答えているのに対し，特教型のM r ・ M $+\mathrm{T}$ a 校や一部型 のNk校では約 $10 \sim 30 \%$ ぼである. 教科型の場合、授業間休 みの多くを次の時間の場所への移動や準備に使っていることがわか る. S e は O m 同様，教科型運営であるが，授業間休みが 20 分と

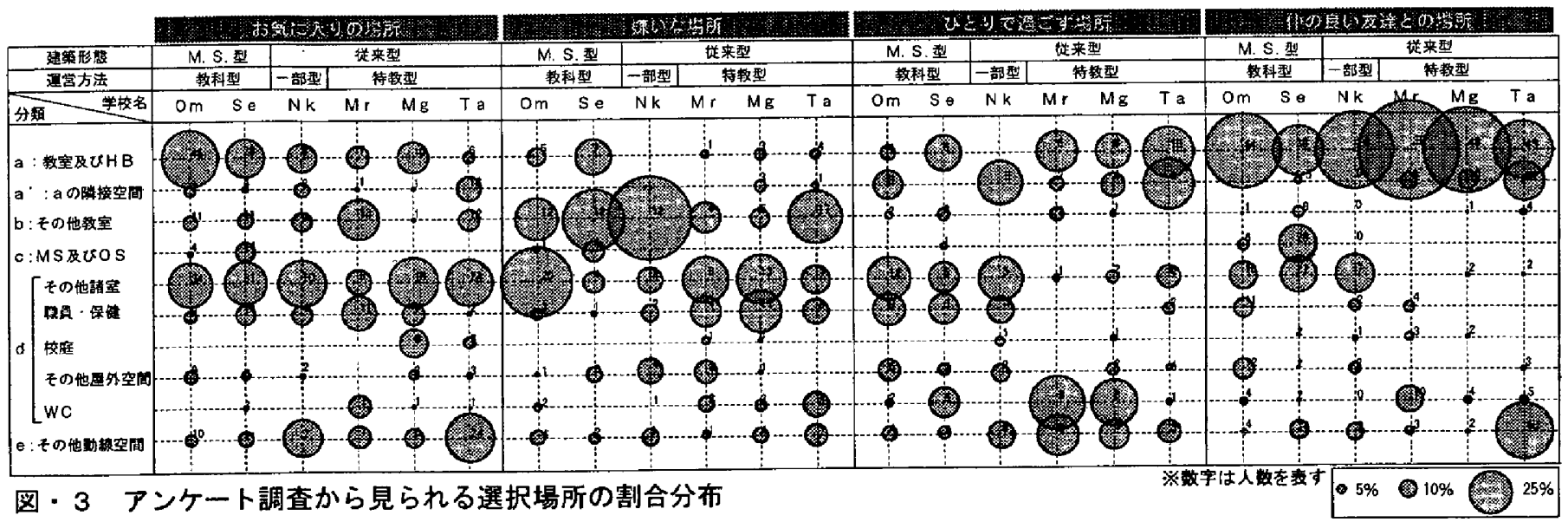


設定されているため，授業間休みを休息時間として利用することが できていることがうかがえる。

また昼休みにおいては，授業間休みと異なり，授業淮備をしてい る生徒はほとんどなく，人や物を介在とした休息行為を行っている 生徒が大半を占めている.

\section{2. 滞在埸所の分布}

授業間体みを実祭にどこで過ごしたかを尋㸚た結果の割合分布を 図・5に，また昼休みにお゙けるその分布を図・6にそれぞれ示した. (1)授業間休み

主にCR・H B での滞在が多く見られる. 教科型の $\mathrm{Om}$ 校, S e 校では，授業場所がその他教室にも及ぶた，滞在場所の分布も $\mathrm{H}$ Bとその他の教室（教科教空及び特別教空）に二極化している.こ れは以下の 2 点に起因するものと考えられる１） H Bが授業潐備 のための立ち寄り場所として有効に使われていること，2）授業が 教科教室や特別教室で行われる教科型では，次の授業の場所で過ご す生徒が多いということ。

一部型である $\mathrm{Nk}$ 校でも，O m户 $\mathrm{m}$ と同様の佰向が見られ る，一方，ほとんどの授業がホームルーム教室で行われる特教型 のM r， M g， T a では，滞在場所はC Rのみに集中している.こ れらの特徽から，授業間休みでは，次の授業が行われる場所で過ご している場合が多く，滞在場所は運営方式に強く関係しているとが わかる。

(2)是休み

$\mathrm{MS}$ 型の $\mathrm{Om}, \mathrm{S} \mathrm{e}$ 校では滞在場所が校内のいくつかの場所に分 散していることがわかる，一方，従来型である $\mathrm{Mr} ， \mathrm{Mg} ， \mathrm{~T}$ a ， $\mathrm{Nk}$ 校では「CR及びCRまわり」と「その他の諸空と動線空間」 に二分されており，昼休みの滞在場所は建築形態に強く関倸してい ると言える，M 型における教科教室や特別教室は，単に授業が行 われる場所としてだけでなく，生活活動の場としても一定の役割を 果たしている。しかし，従来型では休み時間になると特別教空が施 踶されてしまう場合もあり，生徒たちにとって特別教室は生活の場 として認識されていないことがわかる。

\section{3. 昼休みにおける滞在場所と生活行為の関係}

全対象校の5ち，MS型・教科型の $\mathrm{Om}$ 校, 従来型·特教型の $\mathrm{Mr}$ 校, 従来型・一部型の $\mathrm{N} \mathrm{k}$ 校の 3 校考抽出し，昼休みの行為内容の大半 を占める個人の休息行為と滞在場所の関係を図・7に示した．いず れの学校でも，CRやHBでは，友達との会話が多く見られ，CR・ HBが友達と過ごす場所となっていることがわかる．MS 型校舎の Om校では友達と会話をする場所が $\mathrm{H} \mathrm{B}$ Bとどまらず，その他教室
や諸室にまで広がっており，MS型校舎における場所の選択性の高 さを示していると言える、従来型校舍である $\mathrm{N} \mathrm{k}$ では汸下に椅子や $\mathrm{PC}$ ，㔺籍を置くなどの工夫をしているため，動線空間においても 物を介在とした行為を行う生徒の滞在が見られた。 また同じく従来 型校舎のM r では全体的にあまり設えが充実していないものの，一 部廊下にPCを設置しており，その場所における物を介在とした行

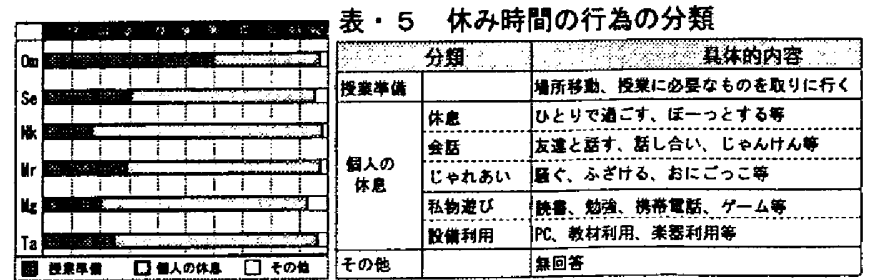

图・4 授集間休みにおける生徒の行為

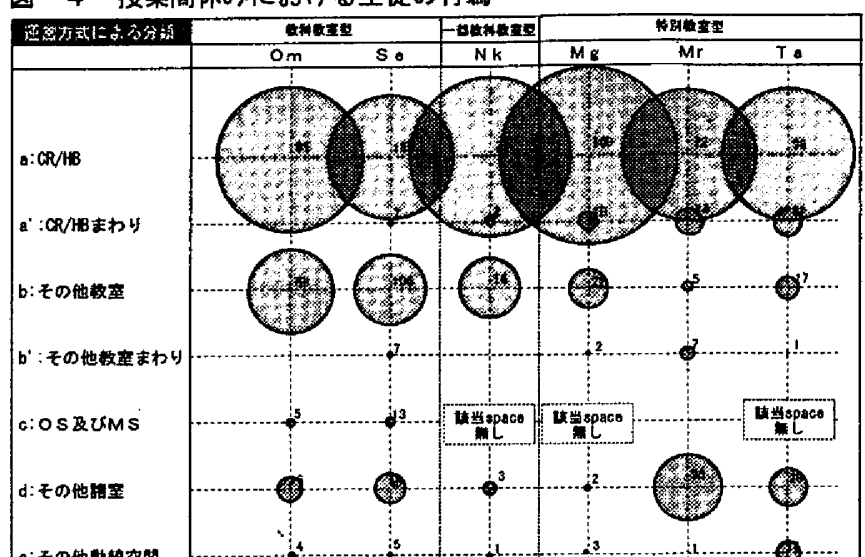

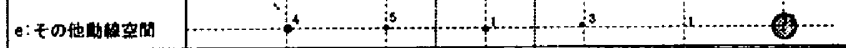

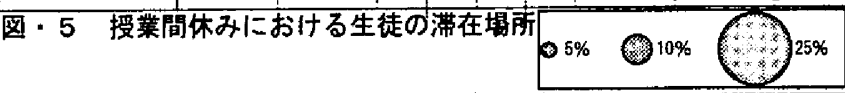

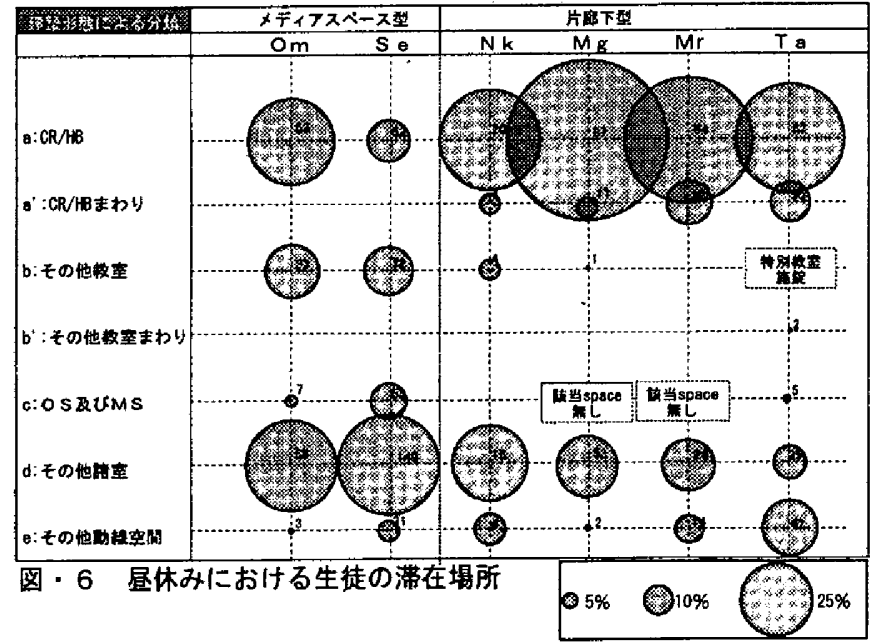

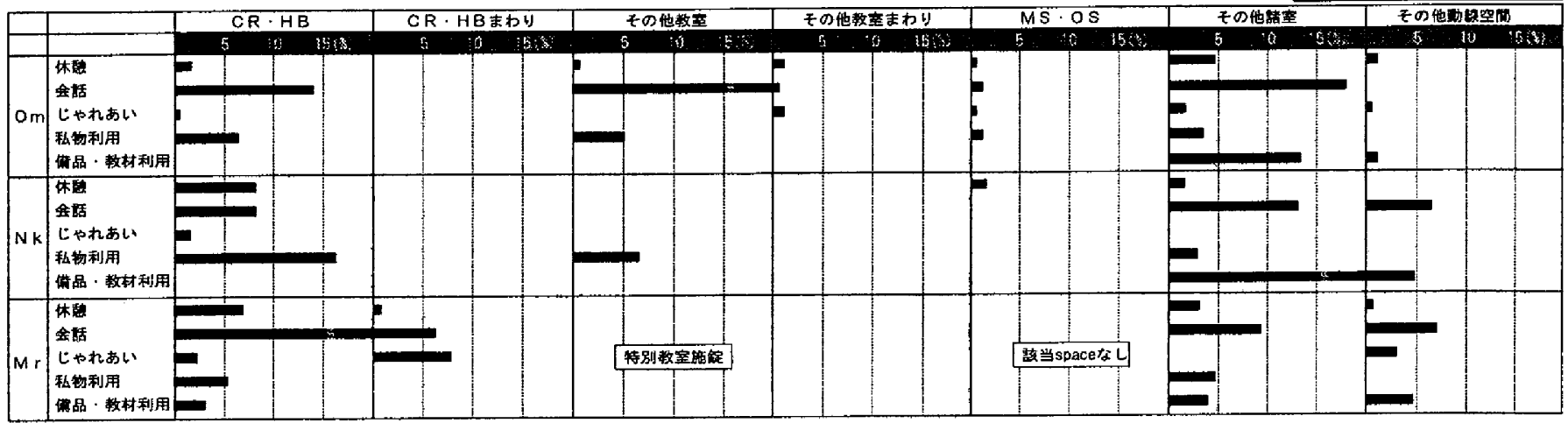

图・7 昼休みにおける人・物を介在とした行為と発生場所との関係 
為が見られた．このことから，谜来型校舎においても設えを工夫す ることなどにより，無機的な空間に場所性が生まれ，生徒の場所の 選択性を高めることができると考えられる。

\section{5. 锶祭調查から見た休み時間の生徒の居畦所と生活活動}

$\mathrm{Mg}$ 除く5校生引)で住，昷休みにおける生徒の居場所について，

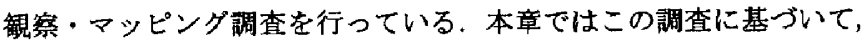
是休みの生徒の滞在場所，行為内容，集団规模について考察を行う.

\section{1. 生徒の居㙕所領域とその展開の分析}

生徒の昼休みの居場所の分布について 2 事例を図・8k示す，さ らに表・4に示した分類毎に生徒の場所別の分布割合を算出した（图・ 9).

従来型・特教型では生徒の滞在の6 割以上がC R と C Rまわりに 集中し，残り 4 割弱の生徒が，図書室などの諸室，または動線空間 に滞在していることがわかる，従来型・特教型では，図書室，体育 館など書籍や備品のある諸室での滞在が多い，MS型・教科型では， 校含内全体に分布が広がっており，各自が自分なりの居場所を見っ けて滞在していることがわかる.日常的に授業のため場所を移動し ているため，行為や教材・備品などのために場所を選択することが 習慣化していると推祭できる．またアンケート調查に基づいた図・ 6と比較してみると，分布に相違が見られる．これは，覤察調査が 第三者の視点によりある時間断面で校内の滞在分布を捉えているの
に対し、アンケート調査では中学生の主稓的視点により回答してい るため，最も多く滞在した場所や目的となる場所を選抧しているた めであると推測される

学年・クラス毎の滞在を見ると，従来型・特教型の場合，学年に より領域が明確に分かれ，他学年と交わることはほとんどないこと が読みとれる。一方，MS型・教科型では，H B以外で居場所領域 が学年别に分かれることはなく，直接的，間接的な学年間の交流が 日常的に起こっていることがわかる. 各連営方式で共通に胃られる 特徽としては，1）MS，OSでは学年や利用集団によるデリトリー が発生しや寸い，2）コーナー性のある空間や，P C・学習資料な どの設備が備わった場所・諸室では，異なる学年や集団が混在する ケースが自られる，3）使用頻度の低い諸室周りには，休み時間生 徒の滞在が少ないが，一部，人の多い場所を避ける生徒の居場所と なる場合がある、などがあげられる。

\section{2. 居場所の分布と行為内容 - 集団規模の関係}

次に，集団規模を 1 人， $2 \sim 3$ 人，4〜6人， 7 人以上の 4 つに 分類し，休み時閒の生徒の行為内容と集団規模の関倸を分析した（図・ $10)$ ．集団の人数に着目寸ると，全ての学校で休み時間を 1 人で過 ごす生徒が見られ，行為内容は休息・私物利用に綍き、書籍やP C などの備品・教材利用が見られた．いずれの学校も，2〜6人の集 団で会話や私物遊び・じやれあいなどを楽しむ生徒が多い．7人以 上の集団形成は全体的に少ないことがわかる.

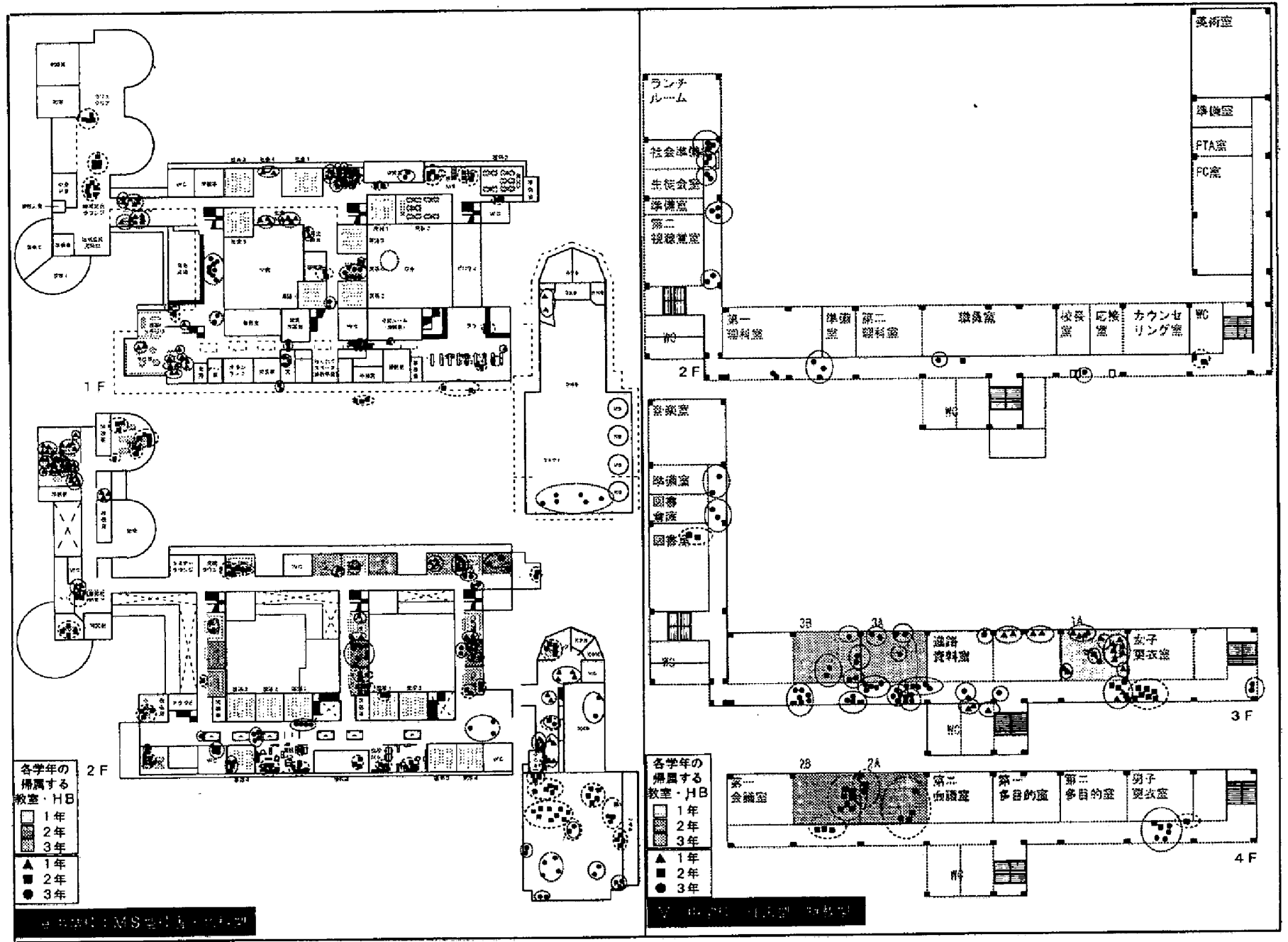

图・8 休み時間の行為と場所との関連 
行為と居場所の関係を見ると（図・11），会話や私物遊びを中心 とした静的な遊びは，CR・HB及び教科教室などで多いことがわ かる。一方，じやれあいなどの動的な遊びは，CR・HBまわりや その他の動線空間など，広いスペースが確保できる場所で行われる 傾向にあることがわかる．教材・備品利用はその他諸室やM S で多 く見られ，設えによって行為や滞在者数が異なっている．校内の各 スペースに本やP C，教材を充実させている S e やOm，Nk校で はそのような物を介在とした行為が多く見られる。しかし，設えが あまり充実していないM r や $\mathrm{T}$ a校では教材・備品利用をする生徒 はあまり見られず，友達と話すなどしながら昼休みを過ごしている 生徒が多く見られた，休み時間の生徒の居場所は，行為や目的，必 要なスペースに応じて適宜選択されていると解釈することができる.

\section{6.まとめ}

本研究で得られた知見を以下にまとめる。

1）生徒各々は「お気に入りの場所」を学年ソーンや普段授業で使 用寸る場所にとらわれることなく選択しているため，必ずしも彼ら が実際に過ごす場所と一政するとは限らない，しかし，全体的な傾 向として，建筑形熊や運営方式に関わらず，教室やH Bに対する生 徒の意識は高く，特に，MS型校舎で設定されているHBは，生徒 のお気に入りの場所であると同時に実際に過ごす場所になっている.

2）生徒の実際の居場所は建築形態に影響を受け、MS型校舎では 場所の選択性が高く，自分たちの行為内容に合わせて場所を選択し やすい環境にあるといえる．このようなことから生徒の活動に対応 する多様な空間を校内全体に点在させることが望ましいと考える。

3）生徒が実際に過ごす場として選択する場所は，日常授業で利用 する領域を超えない場合が多い，しかし，C R・HB以外にもP C や专籍・遊具など，教材や備品利用が可能な場所は居場所として選 択される.よって生徒の場所の選択性を高めるためには，多様な場 を用意するだけでなく，カリキュラム内での積極的な利用や設えの 充実など，運営側の工夫も必要とされる。

4）休み時間の生徒の活動沬多様であり，生徒はそれぞれの活動に 適した場を選んで滞在している．従って，より充実した生活活動の
ために、様々なしつらえや場・空間を設けることが望ましい．

注

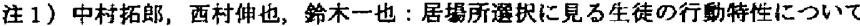

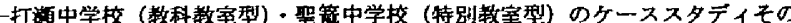
1 一，日本建策学会大会学術請演挭概集 $\mathrm{E}^{-1} 1 ， \mathrm{p} 255 ， 1999$

注 2）濑山大介，西村伸也，大屋信考：ホームベースにおける生徒の居㘿所形成に 関する研究教科教室型へ移行した $\mathrm{S}$ 时立 $\mathrm{S}$ 中学校に打付るケーススタディ，日

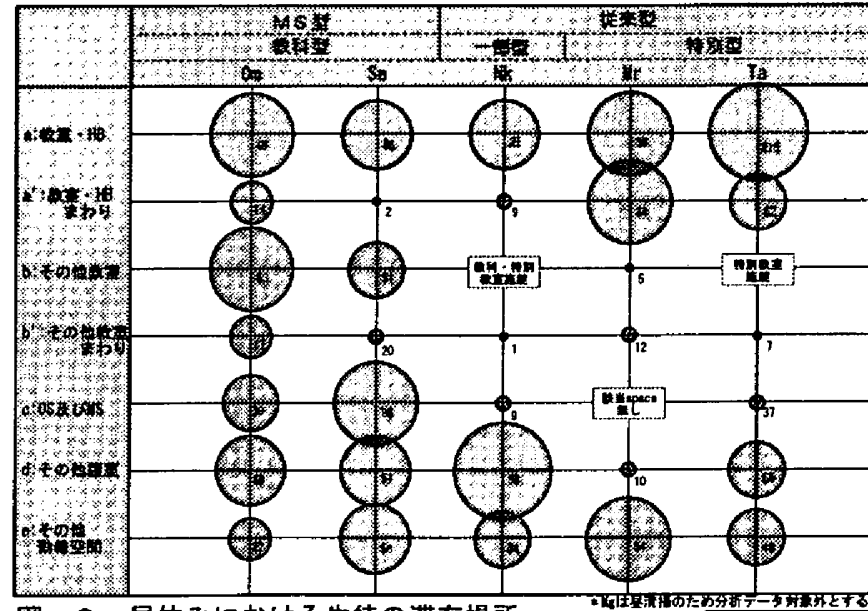

図・9 昼休みにおける生徒の滞在場所

\begin{tabular}{|c|c|c|c|c|c|c|}
\hline & & (1) & $x_{0}$ & $\mathrm{St}^{2}$ & $=\frac{16}{4}$ & 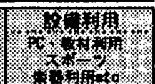 \\
\hline & $1 \curlywedge$ & 0.60060 & & & 0.006 & \\
\hline & $2 \sim 3 \lambda$ & 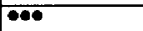 & 7fffithto & $\infty$ & $\infty$ & 0000000000 \\
\hline & $4 \sim 6$ 人 & & 600006060 & 10000 & $\infty 0^{\prime}$ & $\infty$ \\
\hline 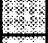 & $7 \Lambda \sim$ & & $\bullet$ & $\cdot$ & & $\cdots$ \\
\hline & 1ᄉᄉ & $\infty$ & & & 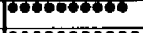 & 880000000 \\
\hline & $2 \sim 3 \lambda$ & - & 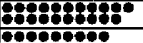 & 0000000000 & $82886838^{\circ}$ & $0^{\circ}$ \\
\hline & $\frac{4 \sim 6 \lambda}{7 \lambda \sim}$ & & 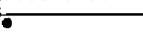 & & & $\%$ \\
\hline & $\hat{1 \Lambda}$ & 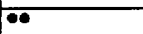 & & & 0 & 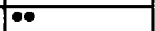 \\
\hline I & $2 \sim 3 \lambda$ & & 00000000 & $\ldots$ & $\infty$ & 00000000 \\
\hline & $4 \sim 6 \lambda$ & & $\because$ & 000 & - & $+\infty$ \\
\hline & $7 \Lambda \sim$ & & & & & \\
\hline & 11 & 0.00000000 & & & $\infty$ & $\bullet$ \\
\hline & $2 \sim 3 \lambda$ & $\because$ & 0000000000 & 0.000 & $\cdots$ & $\cdots$ \\
\hline 1 & $4 \sim 6 \lambda$ & $\bullet$ & 0000 & & $\bullet$ & \\
\hline & $7 \Lambda \sim$ & & - & & & \\
\hline & 1스 & 80000000000 & & & Affftet.0000 & \\
\hline & $\frac{2 \sim 3 \hat{\lambda}}{4 \sim 6 \hat{\lambda}}$ & & Hitimin & 8900000000 & $\because$ & 00000000 \\
\hline & & & 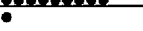 & & • & \\
\hline
\end{tabular}

图・10 㡺休みにおける生徒

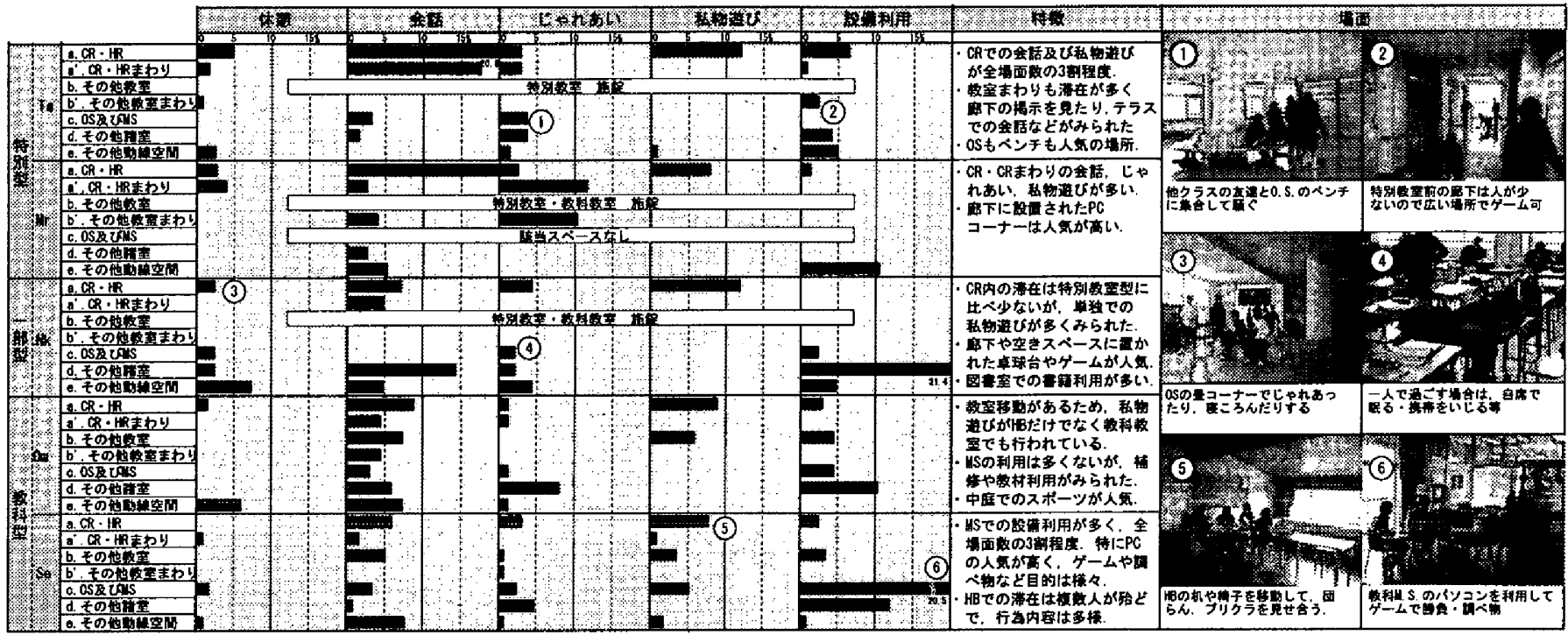

図・11 冝休みの行為と場所との関連 
本建案学会大会学術掼演梗概集 E-1，p71，2003

注 3） $\mathrm{Mg}$ 校では調查実施日が特別時間割であったため，是休みが掃除時間に 葆更されており钼察調查が寒族できなかったため。

\section{考文献}

1）新田佳代，星野賢司，合斗縝子，上野潮：中学校に占ける時間割運用の実 想に基ついた数利别必要数空数の算定について 中学校の建案計画に関する 研究 その 1, 日本建案学会大会学術硾演梗概集 E-1, p25, 2004

2）星野贯司，新田佳代，合斗綾子，上野游：教科数室型中学校における教室・ メディアスペースの使われ方について 中学校の建栄計画に関する研究 そ の2, 日本建策学会大会学術譵演梗概集 $\mathrm{E}-1, \mathrm{p} 27,2004$

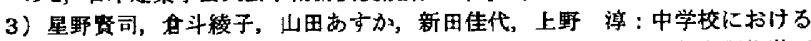
カリキュラム・時間割の実慗からみた教空整備に関する研究一新学習指䓕要 領に対㝒した教科别必要教室数の算定一，日本建案学会技術報告集 第 20 号 p239, 2004

4）新田佳代：学習・生活活動の実態からみた中学校の建築評画に関する研究， H 16 年度東京都立大学大学院修士論文

5) 登坂註人, 新田佳代, 自斗綾子, 常有美, 上野淳: 中学校における生徒の学習 生活活汃の実华 中学校の建策計面に関寸る研究 その1, 日本建筑学会大会

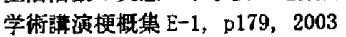

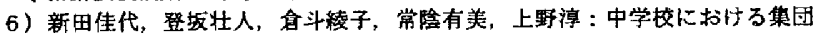
の編成と展開の実態 中学校の建築計画に関する研究 その2, 日本建筑学会 大全学術諈演梗概集 E-1, p181，2005

7）常䧔有美，新田佳代，合斗䍃子，上野淳：中学校に占ける生徒の場所の想 起と居場所の選抧に関する分析」，日本建築学会大会学狱譲演梗概集 E-1， p183, 2005

（2005年 9 月10日原稿受理，2006年 3 月 1 日採用決定） 